NOTE

\title{
Enhancing opportunistic polychaete communities under fish farms: an alternative concept for integrated aquaculture
}

\author{
H. M. Jansen ${ }^{1,2, *}$, P. K. Hansen' ${ }^{1}$ N. Brennan ${ }^{3}$, T. G. Dahlgren ${ }^{4,5}$, J. Fang ${ }^{6,7}$, \\ M. A. J. Nederlof ${ }^{8}$, T. Strohmeier ${ }^{1}$, H. Sveier ${ }^{9}, \varnothing$. Strand $^{1}$ \\ ${ }^{1}$ Institute of Marine Research, Nordnesgaten 50, 5005 Bergen, Norway \\ ${ }^{2}$ Wageningen Marine Research, Wageningen UR, Yerseke 4401 NT, The Netherlands \\ ${ }^{3}$ Department of Biological Sciences, Bergen University, 5020 Bergen, Norway \\ ${ }^{4}$ NORCE Norwegian Research Centre, Postboks 22 Nygårdstangen, 5838 Bergen, Norway \\ ${ }^{5}$ Gothenburg Global Biodiversity Centre and Department of Marine Sciences, University of Gothenburg, 40530 Gothenburg, Sweden \\ ${ }^{6}$ Key Laboratory for Sustainable Utilization of Marine Fisheries Resources, Ministry of Agriculture, \\ Yellow Sea Fisheries Research Institute, Qingdao 266071, PR China \\ ${ }^{7}$ Laboratory for Marine Fisheries Science and Food Production Processes, \\ Qingdao National Laboratory for Marine Science and Technology, Qingdao 266237, PR China \\ ${ }^{8}$ Department of Aquaculture \& Fisheries, Wageningen University, Wageningen 6708 WD, The Netherlands \\ ${ }^{9}$ Lerøy Seafood Group, 5020 Bergen, Norway
}

\begin{abstract}
This note presents the development of benthic integrated aquaculture, addressing a novel cultivation concept for open-water aquaculture. We introduce an approach that supports the colonization of indigenous polychaete communities on benthic cultivation trays deployed in the vicinity of fish-farming cages. Enhancement and subsequent harvest of polychaetes that naturally dominate the local benthic response is essentially different from the classical IMTA approach wherein juveniles and/or seedlings of the extractive species are introduced to the farm site. Results of a field trial showed quick and massive colonization of cultivation trays by polychaetes (predominantly Ophryotrocha craigsmithi) and large spatial variability within the salmon farm site. Our results suggest that enhancing indigenous opportunistic polychaetes is a promising cultivation concept making use of the deposition of organic wastes such as fish faeces and uneaten feed. The methods and results presented here contribute to solutions for technical optimization of benthic IMTA techniques. We expect that further advances in benthic IMTA production will contribute to the expansion of open-water finfish aquaculture within environmentally sustainable boundaries.
\end{abstract}

KEY WORDS: Integrated multi-trophic aquaculture - IMTA · Organic loading · Deposit feeders · Indigenous species · Ophryotrocha

\section{INTRODUCTION}

\subsection{Need for benthic mitigation of fish waste}

Key sustainability issues must be resolved in openwater fish farming to realize the expected potential

${ }^{*}$ Corresponding author: henrice.jansen@wur.nl in future food production from aquaculture. Direct impacts of open-water finfish aquaculture are observed on the seabed in the near vicinity of the fish farms where particulate organic waste (faeces and uneaten feed pellets) settle and change the structure and function of benthic communities and biochemi-

(C) The authors 2019. Open Access under Creative Commons by Attribution Licence. Use, distribution and reproduction are unrestricted. Authors and original publication must be credited. 
cal functioning of the sediment (Kalantzi \& Karakassis 2006, Kutti et al. 2007, Holmer et al. 2008, Bannister et al. 2014). Pelagic waste dispersal and effects on water column processes are less significant (Navarro et al. 2008, Husa et al. 2014, Price et al. 2015, Brager et al. 2016, Jansen et al. 2018). The release of fish wastes into the surrounding environment has fuelled interest in integrated multi-trophic aquaculture (IMTA) (Chopin et al. 2008, Troell et al. 2009, Hughes \& Black 2016), which offers an opportunity to recycle waste streams and simultaneously provide a new source for high-quality marine resources. Recent IMTA developments have been concentrated on integration of suspended bivalves and seaweeds (Chopin et al. 2008, Granada et al. 2016), whereas the integration of benthic deposit feeders has largely been neglected, especially in connection to openwater cage aquaculture. Given the large organic flux and impacts on the benthic system, development of benthic IMTA warrants more attention (Filgueira et al. 2017).

\subsection{Novel approaches for integrated benthic aquaculture}

Polychaetes have been identified as candidate species to convert organic wastes into valuable products and mitigate negative benthic impacts (Kinoshita et al. 2008, Brown et al. 2011, Fang et al. 2017). Some opportunistic polychaetes, specially adapted to high nutrient loads, are naturally abundant in benthic habitats under fish farms and other anthropogenically modified coastal ecosystems (Dahlgren et al. 2004, Kutti et al. 2007, Wiklund et al. 2009a,b, Dafforn et al. 2013, Salvo et al. 2015). The current field study focussed on Norway, where high abundances of polychaetes have been found under salmon cages located over hard bottoms. At those locations, species of the polychaete genera Boudemos and Ophryotrocha form mixed communities in a complex matrix of faecal waste, mucus and bacterial mats (Eikje 2013). Ophryotrocha spp. are also commonly found associated with bacterial mats in soft-sediment habitats under fish farms (Kutti et al. 2007, Paxton \& Davey 2010, Salvo et al. 2015), but densities are highest for hard-bottom sites where mats of Ophryotrocha/Boudemos complexes have been observed covering the entire rocky seafloor underneath the farm (Eikje 2013).

For the development of benthic IMTA, we focussed on techniques that may enhance production of indigenous species, and by development of hardsubstrate structures, we aimed to specifically enhance the Ophryotrocha spp. communities below salmon cages. We assumed that the lack of (hard) substrates limits production under soft-sediment farms, and provision of additional habitat will increase production under hard-bottom farms. This approach is different from most conventional methods that integrate extractive species in the proximity of fish aquaculture (Granada et al. 2016, Hughes \& Black 2016) in the sense that we make use of naturally available populations and do not introduce seedlings, spat or juveniles reproduced in the laboratory or collected at different locations. By providing optimal habitat conditions, the locally existing population is used as a seedling population to stimulate further growth, colonization and reproduction of the polychaete community. Being dependent on indigenous populations, generation times of the local Ophryotrocha species should match the dynamics of fish waste production in order to guarantee that the biomitigation capacity of the polychaetes is fully exploited and wastes are efficiently being turned over. Life cycle and reproduction estimates of 5 Ophryotrocha species indicate fast turnover of the population (days to weeks; Åkesson 1974), but for the species commonly found in Norway, these rates are unknown. Eikje (2013) highlighted that densities under a hard-bottom fish farm in western Norway followed fish production, and thus waste deposition, indicating that the polychaete community dynamics may quickly adapt to varying conditions.

The aim of this study was to evaluate the concept of enhancing local communities by testing if benthic cultivation techniques will attract local Ophryotrocha populations. This may lead to further development and design of equipment to cultivate and harvest polychaetes at commercial scales in order to use their lipids and proteins and to mitigate the organic impact at the site.

\section{MATERIALS AND METHODS}

Prototype trays were developed which consisted of $1 \mathrm{~m}^{2}$ aluminium frames with $5 \mathrm{~cm}$ high edges and a perforated base to allow water to pass through. Plastic substrates with a surface of synthetic fibres were attached to the bottom of the trays. This substrate is assumed to increase surface area for attachment of the polychaetes' mucus complexes and may retain more polychaetes while retrieving the trays to the surface compared to a smooth hard surface. Trays were fastened with shackles and ropes and deployed on the bottom below fish cages. 
A field trial was performed in autumn 2017, where 12 trays were deployed underneath a commercial open-water fish farm in western Norway. The average depth varied between 80 and $250 \mathrm{~m}$, and the bottom consisted of both soft sediment and rocky bottom. The farm consisted of 8 circular cages $(50 \mathrm{~m}$ diameter) arranged in 2 rows (cages 1-4 and 5-8) parallel to the dominant current direction. The current was tidally driven and oriented in a north-south direction, as determined by Doppler acoustic current measurements and model simulations. Standing stock during the field trial was $2878 \mathrm{t}$ of salmon. Trays were placed (a) on the south side of each of the 8 salmon cages, and (b) additional trays were placed on the north side below cages 1, 2, 4 and 8. Tray ID refers to the cage number to which the tray was connected. After a $4 \mathrm{wk}$ deployment period, the trays were retrieved and the polychaete species were identified. Visual identification was subsequently confirmed by DNA sequencing of subsamples $(n=18)$. DNA sequencing was performed using the metazoan cytochrome $c$ oxidase subunit I (COI) barcode gene amplified and sequenced with universal metazoan primers and standard amplification and sequencing protocols (Folmer et al. 1994, Hebert et al. 2003) followed by a BLAST search (https://blast.ncbi.nlm.nih. gov) to match with GenBank data.

It was expected that many polychaetes would be lost during the retrieval of trays from the deployment depths $(80-250 \mathrm{~m})$ to the surface, so non-invasive video inspections (GoPro 5 with additional light) were performed to investigate in situ development of the epifaunal communities on the trays. Video surveys were performed on trays $1 \mathrm{a}, \mathrm{b}, 2 \mathrm{a}, 3 \mathrm{a}, 4 \mathrm{a}, 5 \mathrm{a}$ and $8 \mathrm{a}$ after 2 wk deployment, and at the end of the deployment period (after wk 4) all trays were filmed before retrieval. Videos were analysed by categorizing polychaete coverage as a percentage of tray surface by an expert panel of 9 people.

\section{RESULTS}

The video inspections halfway through the deployment period showed nearly $100 \%$ coverage by Ophryotrocha spp. for at least 1 tray (Tray 1b), indicating that trays can be quickly colonized by Ophryotrocha complexes. Ophryotrocha spp. not only occupied the surface of the trays, but also formed 3D structures, building mucus strings using the ropes and shackles connected to the trays (Fig. 1). This 'vertical behaviour' was previously observed under laboratory conditions (M. A. J. Nederlof pers. obs.). DNA analysis confirmed that the dominant species observed on the trays after retrieval were O. craigsmithi (Fig. 2A). Additionally, soft-substrate species such as Capitella spp. and Malacoceros fuliginosus were found and especially the areas within the substrate blades seemed to serve as a suitable habitat for these polychaetes. Polychaete species observed in low abundances included Prionospio plumosa, O. lobifera and Boudemos ardabilia.

In situ video recordings showed large numbers of Ophryotrocha spp. occupying the surface of the trays, whereas after the trays were brought to surface, it was evident that the numbers had diminished. No correlation was found between in situ coverage (Fig. 2B) and counts after retrieval, demonstrating that the relative species abundance (Fig. 2A) should merely be seen as an indication of presence of domi-
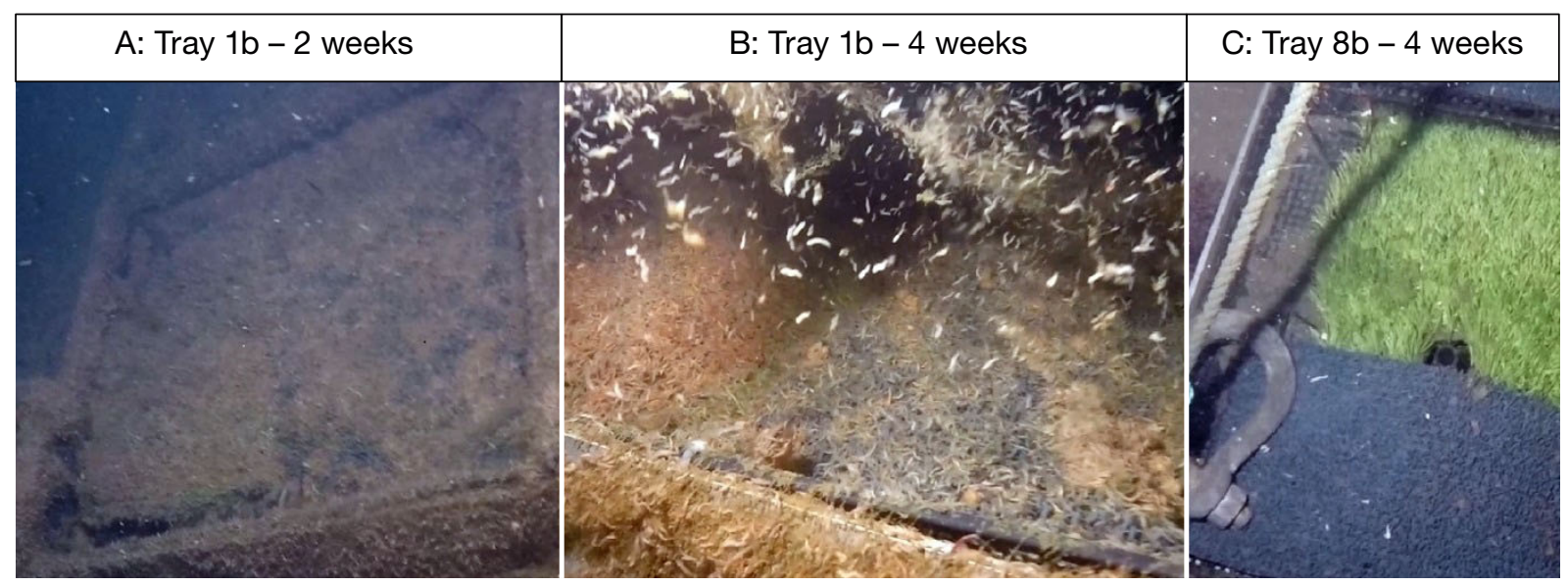

Fig. 1. Inspection by video recordings showing (A) Tray $1 \mathrm{~b}$ after 2 wk of deployment (70-100\% cover), (B) Tray $1 \mathrm{~b}$ after 4 wk of deployment ( $70-100 \%$ cover) and (C) Tray $8 \mathrm{~b}$ after 4 wk of deployment $(<10 \%$ cover) 
A) Relative species abundance

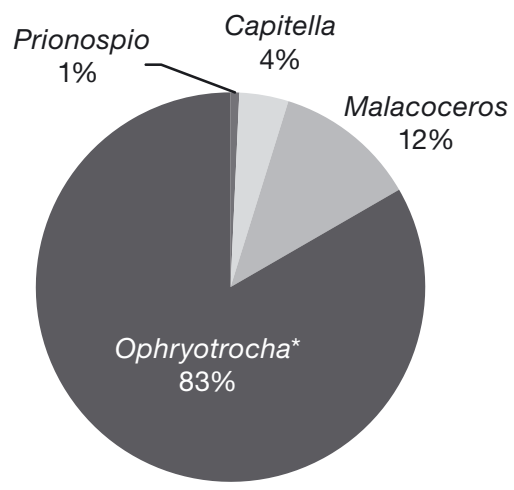

B) Ophryotrocha coverage

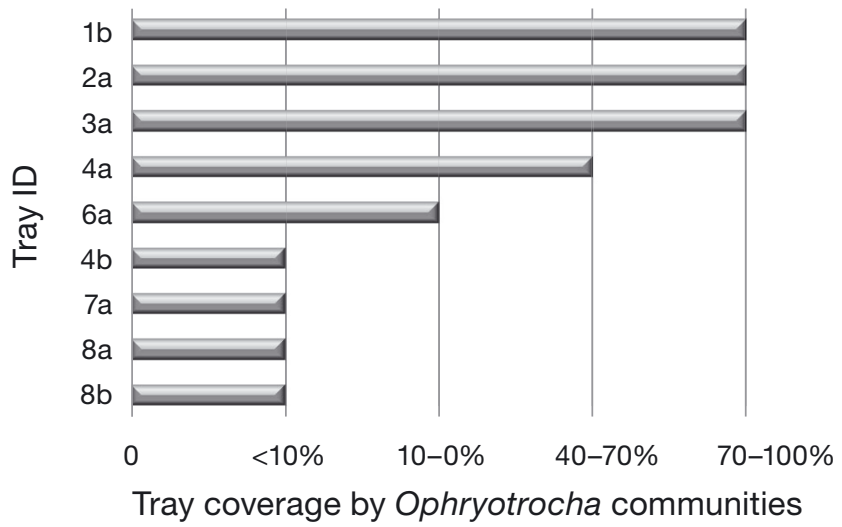

Fig. 2. Polychaete development on benthic cultivation trays. (A) Relative species abundance (\% based on number $\left.\mathrm{m}^{-2}\right)$ determined after retrieval of the cultivation trays. Abundance of Ophryotrocha spp. is underestimated, as an unknown fraction of individuals was lost during retrieval from deployment depth to the surface. (B) In situ measurement of Ophryotrocha coverage (\%) on each tray as determined by video analysis prior to sampling ( $4 \mathrm{wk}$ deployment) and defined by the coverage of the tray surface by the Ophryotrocha complexes (polychaetes including mucus). Tray ID refers to the cage number to which the tray was connected. Trays were placed (a) on the south side of each of the 8 salmon cages, and (b) additional trays were placed on the north side below cages 1, 2, 4 and 8 . The quality of video recordings of Tray $1 \mathrm{a}, 2 \mathrm{~b}$ and $5 \mathrm{a}$ was not sufficient for categorizing the tray coverage and they were therefore omitted

nant species rather than being used for quantification of species abundance. Furthermore, it is likely that the underestimation of the abundance of small polychaetes, such as Ophryotrocha spp., is higher compared to other opportunistic polychaete species, as the mucus/Ophryotrocha complex is easily detached from the surface of the frames during the retrieval process. Furthermore, the primarily infaunal species of Capitella spp. and Malacoceros fuliginosus were embedded in the substrate and more likely to remain captured within the substrate during the retrieval process.

The average abundance of (mean \pm SD) $6200 \pm 5400$ individuals per $\mathrm{m}^{2}(11.1 \pm 9.7 \mathrm{~g}$ ash-free dry weight $\mathrm{m}^{-2}$ ) determined after retrieval is therefore a fraction of the true potential for attraction of Ophryotrocha spp. on the trays. Paxton \& Davey (2010) reported densities of 100000 ind. $\mathrm{m}^{-2}$ for $O$. shieldsi associated with open-water fish farming in Australia, indicating that the potential is indeed much higher than measured after tray retrieval. The difference in Ophryotrocha spp. occurrence between the trays was large, varying from nearly $0 \%$ to almost $100 \%$ coverage after 4 wk of deployment (Fig. 1). A northwest-southeast gradient was observed in the coverage (Fig. 2B), which seemed to correlate with observations of the amount of organic waste from the fish farm on the trays (sediment trap information and amount of organic waste trapped on the frames; data not shown).

\section{DISCUSSION}

\subsection{Succession of polychaete communities under fish farms}

Opportunistic Ophryotrocha spp. have been described as generally short-lived and reproducing quickly (Åkesson 1974, Paxton \& Davey 2010). Given the short deployment duration of the trays, it seems unlikely that fast colonization in the field trial resulted from reproduction, but rather originated from an existing population at the site (Keeley et al. 2015). Yet the attraction of nearby populations suggests a preference of the tray substrate over sediments at the site. Based on life cycle estimates and continuous reproduction patterns in other Ophryotrocha species (days to weeks; Åkesson 1974) and population dynamics of Ophryotrocha complexes underneath Norwegian salmon farms (Eikje 2013), we assume quick reproduction, which suggests a high potential for fast colonization rates on the benthic cultivation trays and thus for biomass production and waste conversion. Organic loading from fish farms seems to be a strong driver for population dynamics of Ophryotrocha spp. communities (Eikje 2013, Salvo et al. 2015). O. craigsmithi feed directly on fish wastes under laboratory conditions (H. M. Jansen pers. obs.), but it remains unresolved whether the microbial loop plays an important role in food acquisition of the polychaetes 
and thereby in waste decomposition (Salvo et al. 2015, Nederlof et al. 2019). Either way, Eikje (2013) reported a significant increase in population size throughout a salmon production cycle but also a steep decrease after the fish were harvested and organic loading disappeared. Visual observations from the field trial also suggested higher Ophryotrocha spp. coverage on trays with higher organic loading. This supports the dependence of Ophryotrocha spp. communities on organic deposition, suggesting a significant role in waste conversion and making them promising candidates for development of integrated benthic aquaculture.

\subsection{Perspective for integrated benthic aquaculture}

Our results from the field trial highlight important factors to consider in the optimization of benthic cultivation techniques in order to further enhance the colonization of Ophryotrocha spp: (1) The characteristics of forming a horizontal and vertical matrix of polychaetes, mucus, organic waste and bacteria suggests that 3D cultivation structures might further stimulate development of Ophryotrocha spp. communities. 3D structures also provide the opportunity for enlarging the cultivation surface area and thus potential for increasing biomass production. It is thereby important that systems will be designed in such a way that wastes will reach all sections of the 3D structure. (2) Two substrates varying in fibre length were tested during the field trial and resulted in similar colonization of Ophryotrocha spp. and infaunal polychaetes; however, further development of benthic cultivation trays could still benefit from evaluation of alternative substrates. (3) To be able to design the optimal cultivation systems, more insight is needed into the role of mucus and associated bacteria in the life cycle of Ophryotrocha spp., as it is still largely unknown to what extent degraded flocculent organic matter, fresh fish pellets or bacterial mats contribute to the diet of the different Ophryotrocha species (Salvo et al. 2015). (4) Cultivation trays were placed directly on the bottom underneath salmon cages, but to decrease the level of impact on the seafloor and preserve natural habitats, cultivation trays suspended in the water column may have advantages. It is still unknown what the optimal or maximum height is above the seafloor that will result in high attraction of Ophryotrocha complexes. Moving up in the water column does require critical evaluation of fish farm-polychaete interactions apart from organic loading, for example potential negative effects of medicine residues (Fang et al. 2018). (5) Depth of deployment will influence the functioning of benthic habitats underneath the suspended trays in terms of water currents or/and oxygen supply, and effects should be minimized in order to have the least effect on the health status of the bottom. (6) Trays should be deployed long enough to provide a habitat for colonizing and reproducing polychaetes, yet there could potentially be an optimum deployment time, or repetitive harvest strategies could be envisioned throughout the production cycle. This should be evaluated together with making a biological assessment of the generation times and driving factors for reproduction, specifically for Ophryotrocha craigsmithi. (7) Losses of polychaetes during retrieval of the trays demonstrates the need for efficient harvest methods, both from a commercial perspective as well as for research purposes. Systems that can collect polychaetes before retrieval would thereby be optimal (e.g. by sealing [parts of] the trays, or by suction devices that collect polychaetes from the trays). Depth of the farm location will determine whether this can be done by diving or by remotely operated techniques.

The production potential of $O$. craigsmithi under laboratory conditions (Nederlof et al. 2019) is high in comparison to Nereis virens used in recirculating aquaculture systems and pond-integrated aquaculture (Brown et al. 2011), or to soft-sediment opportunistic Capitella spp. cultured under a shallow fish farm in Japan (Kinoshita et al. 2008). Furthermore, the body composition of $O$. craigsmithi seems interesting as an alternative high-quality marine resource (Nederlof et al. 2019). The deployment of benthic trays has been shown to attract dense Ophryotrocha communities, indicating that the alternative IMTA concept of enhancing indigenous species may be a promising approach for benthic cultivation in integrated open water systems. Besides optimization of the benthic cultivation design, follow-up studies will evaluate the role of Ophryotrocha spp. and other species attracted to the benthic cultivation trays in waste recycling and assess their economic potential as a new high-quality marine resource. Combined, this allows us to assess the potential of integrated aquaculture using novel benthic cultivation techniques.

Acknowledgements. This work was supported by Ocean Forest AS (Research and Development licence FD00361608763/Institute of Marine Research). We thank the staff at Lerøy Vest AS for their assistance during deployment and retrieval of the benthic cultivation trays. 


\section{LITERATURE CITED}

Åkesson B (1974) Reproduction and larval morphology of five Ophryotrocha species (Polychaeta, Dorvilleidae). Zool Scr 2:145-155

Bannister RJ, Valdemarsen T, Hansen PK, Holmer M, Ervik A (2014) Changes in benthic sediment conditions under an Atlantic salmon farm at a deep, well-flushed coastal site. Aquacult Environ Interact 5:29-47

Brager LM, Cranford PJ, Jansen H, Strand Ø (2016) Temporal variations in suspended particulate waste concentrations at open-water fish farms in Canada and Norway. Aquacult Environ Interact 8:437-452

Brown N, Eddy S, Plaud S (2011) Utilization of waste from a marine recirculating fish culture system as a feed source for the polychaete worm, Nereis virens. Aquaculture 322-323:177-183

Chopin T, Robinson SMC, Troell M, Neori A, Buschmann AH, Fang JG (2008) Multitrophic integration for sustainable marine aquaculture. In: Jørgensen SE, Fath BD (eds) Ecological engineering. Encyclopedia of ecology, Vol 3. Elsevier, Oxford, p 2463-2475

Dafforn KA, Kelaher BP, Simpson SL, Coleman MA and others (2013) Polychaete richness and abundance enhanced in anthropogenically modified estuaries despite high concentrations of toxic contaminants. PLOS ONE 8:e77018

Wahlgren TG, Glover AG, Baco A, Smith CR (2004) Fauna of whale falls: systematics and ecology of a new polychaete (Annelida: Chrysopetalidae) from the deep Pacific Ocean. Deep Sea Res I 51:1873-1887

Eikje E (2013) Benthic impacts of fish-farm waste on hard bottom habitats, the ecology of opportunistic epifauna polychaetes. MSc thesis, University of Bergen

Fang JH, Jiang ZJ, Jansen HM, Hu FW and others (2017) Applicability of Perinereis aibuhitensis Grube for fish waste removal from fish cages in Sanggou Bay, PR China. J Ocean Univ China 16:294-304

Fang J, Samuelsen OB, Strand Ø, Jansen H (2018) Acute toxic effects of hydrogen peroxide, used for salmon lice treatment, on the survival of polychaetes Capitella sp. and Ophryotrocha spp. Aquacult Environ Interact 10:363-368

Filgueira R, Guyondet T, Reid GK, Grant J, Cranford PJ (2017) Vertical particle fluxes dominate integrated multitrophic aquaculture (IMTA) sites: implications for shellfish-finfish synergy. Aquacult Environ Interact 9:127-143

Folmer O, Black M, Hoeh W, Lutz R, Vrijenhoek R (1994) DNA primers for amplification of mitochondrial cytochrome $c$ oxidase subunit I from diverse metazoan invertebrates. Mol Mar Biol Biotechnol 3:294-299

* Granada L, Sousa N, Lopes S, Lemos MFL (2016) Is integrated multitrophic aquaculture the solution to the sectors' major challenges? - a review. Rev Aquacult 8:283-300

Hebert PDN, Cywinska A, Ball SL, DeWaard JR (2003) Biological identifications through DNA barcodes. Proc R Soc B 270:313-321

Holmer M, Black K, Duarte CM, Marbà N, Karakassis I (2008) Aquaculture in the ecosystem. Springer, Dordrecht

Hughes AD, Black KD (2016) Going beyond the search for solutions: understanding trade-offs in European inte-

Editorial responsibility: Dror Angel,

Haifa, Israel grated multi-trophic aquaculture development. Aquacult Environ Interact 8:191-199

Husa V, Kutti T, Ervik A, Sjotun K, Hansen PK, Aure J (2014) Regional impact from fin-fish farming in an intensive production area (Hardangerfjord, Norway). Mar Biol Res 10:241-252

Jansen HM, Broch OJ, Bannister R, Cranford P and others (2018) Spatio-temporal dynamics in the dissolved nutrient waste plume from Norwegian salmon cage aquaculture. Aquacult Environ Interact 10:385-399

Kalantzi I, Karakassis I (2006) Benthic impacts of fish farming: meta-analysis of community and geochemical data. Mar Pollut Bull 52:484-493

Keeley NB, Forrest BM, Macleod CK (2015) Benthic recovery and re-impact responses from salmon farm enrichment: implications for farm management. Aquaculture 435:412-423

Kinoshita K, Tamaki S, Yoshioka M, Srithonguthai S and others (2008) Bioremediation of organically enriched sediment deposited below fish farms with artificially mass-cultured colonies of a deposit-feeding polychaete Capitella sp. I. Fish Sci 74:77-87

Kutti T, Hansen PK, Ervik A, Hoisaeter T, Johannessen P (2007) Effects of organic effluents from a salmon farm on a fjord system. II. Temporal and spatial patterns in infauna community composition. Aquaculture 262:355-366

*Navarro N, Leakey RJG, Black KD (2008) Effect of salmon cage aquaculture on the pelagic environment of temperate coastal waters: seasonal changes in nutrients and microbial community. Mar Ecol Prog Ser 361:47-58

Nederlof MAJ, Jansen HM, Dahlgren TG, Fang J and others (2019) Application of polychaetes in (de)coupled integrated aquaculture: production of a high-quality marine resource. Aquacult Environ Interact 11:221-237

*Paxton H, Davey A (2010) A new species of Ophryotrocha (Annelida: Dorvilleidae) associated with fish farming at Macquarie Harbour, Tasmania, Australia. Zootaxa 2509: 53-61

* Price C, Black KD, Hargrave BT, Morris JA Jr (2015) Marine cage culture and the environment: effects on water quality and primary production. Aquacult Environ Interact 6: $151-174$

Salvo F, Hamoutene D, Dufour SC (2015) Trophic analyses of opportunistic polychaetes (Ophryotrocha cyclops) at salmonid aquaculture sites. J Mar Biol Assoc UK 95: 713-722

Troell M, Joyce A, Chopin T, Neori A, Buschmann AH, Fang JG (2009) Ecological engineering in aquaculture - potential for integrated multi-trophic aquaculture (IMTA) in marine offshore systems. Aquaculture 297:1-9

Wiklund H, Glover AG, Dahlgren TG (2009a) Three new species of Ophryotrocha (Annelida: Dorvilleidae) from a whale-fall in the North-East Atlantic. Zootaxa 2228: 43-56

*Wiklund H, Glover AG, Johannessen PJ, Dahlgren TG (2009b) Cryptic speciation at organic-rich marine habitats: a new bacteriovore annelid from whale-fall and fish farms in the North-East Atlantic. Zool J Linn Soc 155: $774-785$

Submitted: January 2, 2019; Accepted: March 27, 2019 Proofs received from author(s): July 3, 2019 